\title{
PERAWATAN FRAKTUR KELAS TIGA ELLIS PADA GIGI TETAP INSISIF SENTRAL ATAS (Laporan Kasus)
}

\section{Eva Fauziah, Hendrarlin S}

\author{
Departemen Ilmu Kedokteran Gigi Anak Fakultas Kedokteran Gigi Universitas Indonesia
}

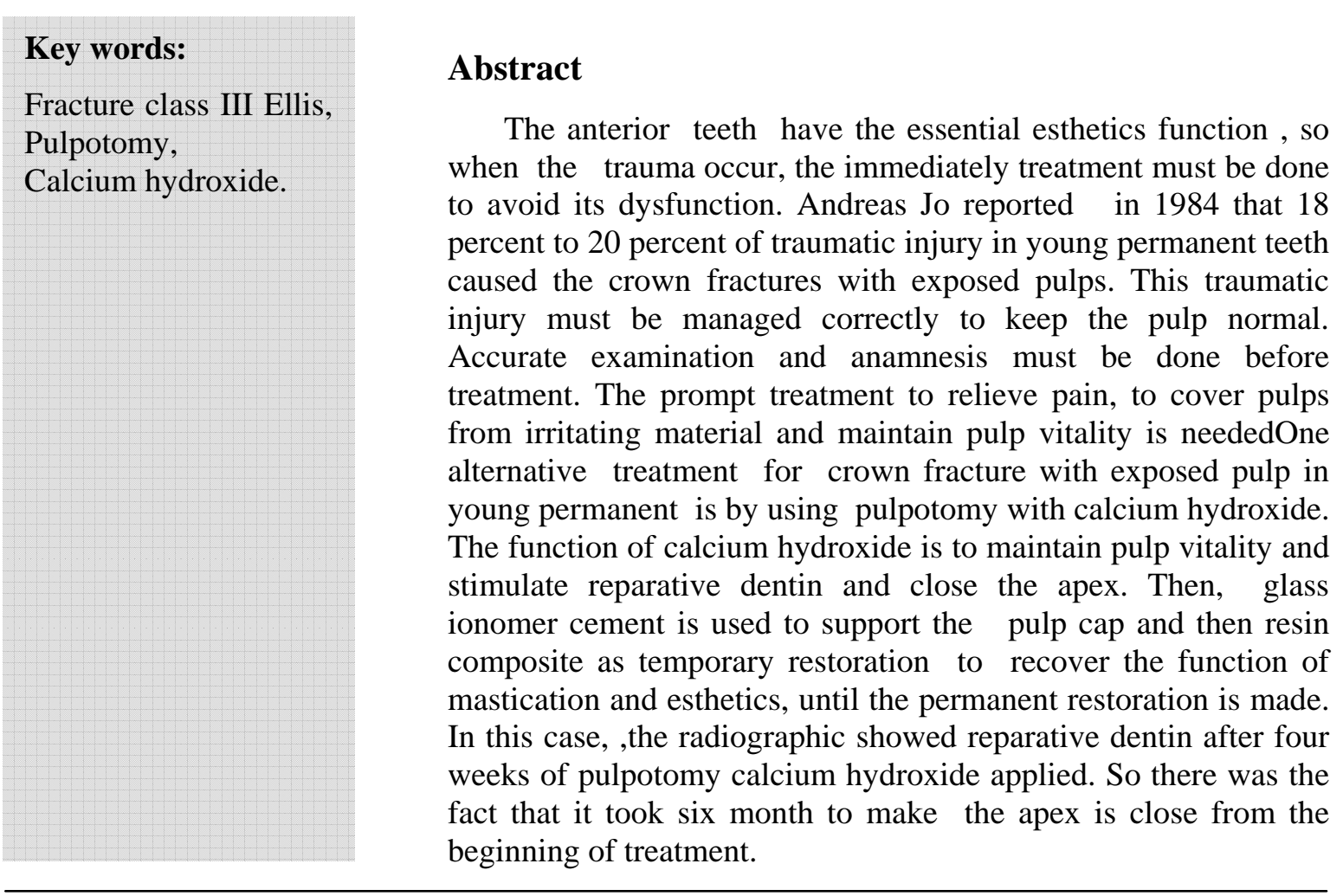

\section{Pendahuluan}

Gigi anterior memiliki fungsi estetik. Bila terjadi trauma pada gigi anterior harus segera dilakukan perawatan agar tidak kehilangan fungsinya. Penyebab trauma secara garis besar tergantung kepada usia anak. Sebagian besar 
trauma pada gigi sulung terjadi pada usia 1,5 - 2 tahun, yakni pada saat anak belum dapat berjalan stabil. Seiring dengan anak mulai dapat berjalan sendiri, sering kali mereka jatuh ke arah depan, dengan bertumpu pada kedua tangan dan lututnya. Antara usia 5-11 tahun, trauma terjadi karena terjatuh saat bermain, berolahraga, berlari dan bersepeda. ${ }^{1}$ Perbedaan distribusi trauma pada anak laki-laki dan wanita hingga umur 9 tahun tidak begitu nyata, tetapi setelah umur tersebut, Trauma pada gigi anterior pada anak laki-laki cenderung dua kali lebih banyak dibanding pada anak perempuan. Hal ini mungkin disebabkan karena mereka lebih aktif berpartisipasi dalam permainan dan olahraga dibandingkan dengan anak perempuan. ${ }^{1}$ Trauma pada gigi anterior menunjukkan prevalensi yang cukup tinggi. Ellis dan Davey melaporkan 4251 anak sekolah di kota besar 4,2\% memiliki fraktur gigi anterior. $^{2}$ Sementara Marcus dan Gutz dalam penelitian terpisah melaporkan frekuensi yang lebih tinggi, sekitar $16 \%-20 \% .^{3}$ Andreas Jo, 1984 melaporkan bahwa 18\%-20\% trauma pada gigi tetap muda, menyebabkan fraktur mahkota dengan pulpa terbuka. ${ }^{4}$ Fraktur mahkota dengan pulpa terbuka ini harus segera diatasi untuk melindungi pulpa agar tetap normal. ${ }^{5}$

Penyebab dari trauma itu sendiri dapat terjadi langsung atau tidak langsung. Dan didukung oleh faktor predisposisi yang meliputi faktor eksternal, karena permainan yang berbahaya dan faktor internal, karena posisi gigi anterior yang protusif .

Sejumlah klasifikasi fraktur karena trauma sangat diperlukan, sehingga standard prosedur perawatan dapat ditentukan. Kennedy menyatakan "tidak ada cabang dari ilmu kedokteran gigi mempunyai kemajuan yang sangat cepat sampai kasusnya terklasifikasi”. Ellis mengklasifikasikan trauma gigi menjadi 8 kelas. $^{2}$ Sedangkan menurut Andreasen mengklasifikasi-kan menjadi 4 kelas meliputi trauma yang mengenai gigi, jaringan pendukung, gingival dan oral mukosa. ${ }^{4}$ Pasien dengan fraktur yang sudah mengenai pulpa karena trauma, mengungkapkan adanya keluhan kepekaan terhadap perubahan suhu, sakit saat berfungsi, selain itu pasien mengalami sakit saat makan atau minum yang manis atau asam. Pemeriksaan pasien yang mengalami fraktur terdiri dari pemeriksaan darurat dan pemeriksaan lanjutan. Pemeriksaan da ruratmeliputi pengu-mpulan data vital, riwayat kesehatan pasien, data dan keluhan pasien. Data vital terdiri dari usia pasien, bagaimana dan dimana terjadinya trauma serta kapan terjadinya trauma. Apabila terjadinya trauma ditempat yang kotor atau kemungkinan banyak bakteri dan mengakibatkan keadaan klinis kemerahan, pembengkakan pada ginggiva, maka pasien perlu diberikan ATS (Anti Tetanus Serum). Pasien juga ditanyakan apakah terjadi muntah pada saat trauma, atau pasien menjadi tidak sadar, sakit kepala serta amnesia setelah mengalami trauma. Apabila hal ini terjadi maka kemungkinan ada kerusakan pada sistem syaraf pusat. Maka pasien dianjurkan untuk pemeriksaan lebih lanjut pada bagian neurologi. ${ }^{6}$

Pemeriksaan lanjutan meliputi pemeriksaan kembali klinis lengkap yang terdiri dari pemeriksaan ekstra oral dan intra oral serta dilakukan pemeriksaan penunjang y aitu pemeri-ksaan radiografis, untuk dapat melihat perkembangan akar, ukuran pulpa dan jarak dengan garis fraktur, kelainan pada dan jaringan pendukung. ${ }^{1,3,2,4}$

Perawatan yang dilakukan pada fraktur yang mengenai pulpa, diusahakan dapat mempertahan-kan vitalitas pulpa. Ada beberapa hal yang harus diperhatikan dalam perawatan fraktur mengenai pulpa, yakni besarnya pulpa yang terbuka, vitalitas pulpa, lamanya pulpa terbuka, derajat pembentukan akar dan kemungkinan mahkota untuk dapat direstorasi. Alternatif perawatan yang dapat dilakukan, yaitu pulpotomi, parsial pulpotomi dan pulpektomi.

Pulpotomi merupakan perawatan yang hanya mengambil jaringan pulpa terinfeksi pada kamar pulpa, dan mempertahankan jaringan pulpa vital dalam saluran akar. Pada gigi yang immature, perkembangan akar akan terus berlanjut apabila pulpa dalam saluran akar dipertahankan tetap sehat. Pulpotomi dapat dilakukan pada gigi dengan pulpa terbuka 
tidak lebih dari 72 jam. ${ }^{3}$ Berdasarkan penelitian lain, oleh Lucia Blanco, Stephen Cohen membuktikan bahwa ukuran pulpa yang terbuka serta waktu antara terjadinya trauma dengan perawatan dan sempurnanya pembentukan akar merupakan salah satu hal yang tidak terlalu penting untuk dapat mencapai perawatan pulpotomi yang optimal. ${ }^{5}$ Sedangkan parsial pulpotomi adalah perawatan yang hanya mengambil daerah tanduk pulpa. Pengambilan daerah tersebut sangat minimal karena jaringan pulpa mempunyai vaskularisasi yang baik, dan dapat memberikan reaksi pertahanan terhadap kontaminasi bakteri. ${ }^{5}$ Dan pulpektomi dilakukan dengan cara pengangkatan pulpa secara keseluruhan dari kamar pulpa dan saluran akar. Perawatan ini diindikasikan bila pulpa mengalami degenerasi atau vitalitas pulpa diragukan dan dapat dilakukan apabila akar telah tertutup sempurna. ${ }^{3}$

Salah satu bahan yang digunakan untuk pulpotomi adalah kalsium hidroksida. Bahan ini dugunakan karena sifat biokompatiblenya, disampi -ng itu mempunyai sifat yang menguntungkan seperti anti bakteri, isolator termis, dapat diterima oleh semua bahan tumpatan karena tidak mempunyai reaksi yang berlawanan. Sebagai bahan pelindung, ia dapat menahan penetrasi asam. Dalam penelitian diketahui bahwa kalsium hidroksida tidak secara langsung berperan dalam proses mineralisasi, tetapi mempunyai peranan dalam merangsang odontoblas, sedangkan mineralisasi dan matriks dentin dipengaruhi kalsium darah yang berasal dari sirkulasi sistemik. ${ }^{4,7}$ Kalsium Hidroksida juga dapat membentuk selapis tipis jaringan koagulasi nekrosis karena bahan ini mempunyai derajat iritasi yang rendah pada pulpa dan dapat merangsang formasi pertahanan jaringan keras. ${ }^{8}$ Berdasarkan hasil penelitian, diketahui bahwa hasil reaksi jaringan dentin terhadap kalsium hidroksida terjadi pada hari pertama hingga minggu kesembilan. Ellis dan Davey menganjurkan untuk mengamati pembentukkan dentin sekunder setelah waktu 68 minggu perawatan. ${ }^{2}$ Sedangkan pada penelitian yang dilakukan oleh Lucia Blanco, Stephen Cohen formasi awal dari dentin sekunder terbentuk 7 hari setelah perawatan pulpotomi dengan kalsium hidroksida. ${ }^{5}$

Kalsium hidroksida yang dapat digunakan berbentuk powder dan pasta. Bentuk powder digunakan dengan mencampurkan bubuk powder dengan aquadest. Bentuk pasta terdiri pasta base dan pasta katalis. Bahan ini digunakan dengan cara mengaduk kedua pasta campuran yang homogen, kemudian diulaskan pada lapisan pulpa yang terbuka. Pemberian harus cermat dan dicegah jangan sampai mengenai email, karena bahan mudah larut dan akan menyebabkan kebocoran pada tepi tumpatan. ${ }^{9}$

Selanjutnya untuk mendukung bahan pelindung, antara lain dapat digunakan bahan semen ionomer kaca dan semen zinc phosphat. Kedua bahan ini memiliki biokompatibilitas terhadap pulpa. Kelebihan semen ionomer kaca dibandingkan dengan yang lain, bahan ini mampu melepaskan flour, dan memiliki koefesien termal ekspansi yang sama dengan jaringan gigi. $^{10}$

Bahan resin komposit dapat berfungsi sebagai temporary permanent restoration. Ditinjau dari segi iritasi pulpa komposit lebih baik dibanding bahan lainnya. Dan secara estetik, bahan komposit dapat memberi hasil yang baik dan permukaan tidak menjadi kasar. ${ }^{10}$ Seperti diketahui gigi anterior harus dapat memberikan nilai estetik yang lebih. Anak dalam usia sekolah yang mengalami perkembangan mental dan sosial menjadi lebih peka apabila adanya suatu kelainan atau restorasi yang tidak memuaskan karena adanya fraktur gigi. Menurut Brauer, kadang-kadang hal ini dapat membuat perasaan rendah diri, yang merupakan faktor langsung kegagalan anak dimasa yang akan datang. ${ }^{2}$ Untuk itu diperlukan restorasi yang memberikan nilai estetik dan memuaskan diri pasien pada kasus fraktur gigi anterior pada anak-anak.

Dalam laporan kasus ini, akan dibahas mengenai perawatan fraktur gigi tetap insisif sentral atas dengan pulpa terbuka karena trauma, pada anak laki-laki usia 10 tahun. 


\section{Kasus}

Seorang anak laki-laki, usia 10 tahun, tinggi badan $133 \mathrm{~cm}$ dan berat nadan $29 \mathrm{Kg}$, datang ke klinik Kedokteran Gigi Anak FKG UI pada tanggal 2 Juli 2003, dengan keluhan gigi depan atas sakit atau ngilu bila makan makanan manis dan minuman dingin. 1 minggu yang lalu sebelum penderita jatuh dilantai saat berlari didalam rumah dan gigi depan atas patah sebagian. Keadaan umum anak baik, dapat berkomunikasi, tidak dalam perawatan dokter, anak dalam keadaan sehat, tidak mempunyai kebiasaan buruk.

Pemeriksaan ekstra oral muka simetris, tidak ada pembengkakan kelenjar getah bening, sub mandibular dan sub mentalis. Pada pemeriksaan intra oral, tidak ada kelainan jaringan lunak. Status oklusi klasifikasi Angle kelas I tipe 2, dengan multiple diastema. Skor plak 15 dengan indeks plak 2,5. Gigi 21 mengalami fraktur mahkota dengan pulpa terbuka. Pada perabaaan dengan kapas menimbulkan rasa ngilu. Tidak terdapat nyeri tekan dan kegoyangan pada gigi tersebut. Gambaran radiografik gigi 21: menampakkan mahkota fraktur sepertiga tengah, sudah mencapai pulpa, dan adanya radiolusensi di daerah apical karena apeks gigi belum tertutup sempurna.

\section{Tata Laksana Kasus}

Diagnosa 21 fraktur mahkota mencapai pulpa, vital (menurut klasifikasi ELLIS, fraktur kelas III) Pemeriksaan karies dijumpai 75,85 KMP non vital dengan gambaran radiografis resorbsi akar sudah mencapai seperiga servikal, benih gigi tetap 35,45 sudah menembus tulang dan pertumbuhan gigi tetap sudah mencapai sepertiga servikal. Gigi 54 karies dentin, 55, 13,23 karies email. Rencana perawatan sebagai berikut: DHE dan OP, 21 pulpotomi dengan Ca $(\mathrm{OH}) 2$ - dengan restorasi komposit. Perawatan gigi lain sesuai dengan indikasi dan topical aplikasi dengan larutan flour dan pro orthodonti.

Pada kunjungan pertama,dilakukan pemeriksaan lengkap, DHE dan OP, gigi 21 pulpotomi dengan $\mathrm{Ca}(\mathrm{OH}) 2$ dan di semen dengan semen ionomer kaca. Seminggu kemudian dilakukan kontrol, tidak ada keluhan dan secara klinis tidak ditemukan adanya kelainan. Pada minggu keempat dilakukan kontrol secara klinis dan radiografis. Secara klinis tak ada keluhan dan kelainan. Dan hasil rontgen menunjukkan terbentuknya dentin sekunder. Selanjutnya dilakukan restorasi resin komposit. Dilakukan kontrol 1 minggu dan hasilnya tumpatan masih baik. Kontrol setelah 1 bulan menunjukkan tumpatan juga masih baik, dan reaksi positif atas rasa dingin. Kontrol setelah 6 bulan memperlihatkan tumpatan masih baik, serta vitalitas gigi positif. Pemeriksaaan radiografi tidak tampak ada kelainan dan apeks tertutup sempurna. Pasien dianjurkan untuk datang kembali setelah 1 tahun, dan 2 tahun, guna mengontrol keadaan giginya. Bila ada keluhan yang timbul dianjurkan segera datang untuk pemeriksaan dan perawatan lebih lanjut. ${ }^{2,3,4}$

\section{Pembahasan}

Trauma gigi tetap insisif sentral atas pada anak usia 10 tahun sering terjadi. Hal ini dikarenakan pada usia tersebut anak sedang aktif bermain, berolahraga, berlari dan bersepeda. Dan didukung juga oleh keadaan gigi pasien yang protusif anterior. Pada kasus ini trauma terjadi saat anak sedang jatuh di dalam rumah. Berdasarkan riwayat dimana terjadinya trauma maka pada pasien ini tidak dianjurkan untuk pemberian ATS.

Alternatif perawatan yang dipilih pada kasus ini adalah pulpotomi. Keuntungan pemilihan perawatan pulpotomi adalah pengambilan jaringan pulpa terinfeksi seluruhnya pada kamar pulpa dan dapat mempertahankan pulpa vital dalam saluran akar. Kasus ini menunjukkan pembentukkan akar yang masih belum sempurna, dengan mempert ahankan pulpa dalam saluran akar tetap sehat, maka perkembangan akar akan terus berlanjut. ${ }^{3}$ Sedangkan parsial pulpotomi tidak dilakukan karena pada perawatan ini hanya mengambil bagian tanduk pulpa secara minimal. ${ }^{5}$ Pada pasien ini, pulpa sudah terbuka luas selama satu 
minggu, kontaminasi bakteri diperkirakan sudah meluas hingga kamar pulpa. Sehingga perawatan parsial pulpotomi tidak dilakukan.

Pasien datang dan dilakukan pulpotomi dengan kalsium hidroksida setelah 1 minggu mengalami trauma. Berbeda dengan pulpotomi yang biasa dilakukan pada gigi dengan pulpa terbuka tidak lebih dari 72 jam. Hal ini tidaklah menjadi masalah, karena berdasarkan penelitian yang dilakukan Lucia Blanco, Stephen Cohen ukuran pulpa yang terbuka serta waktu antara terjadinya trauma dengan perawatan dan sempurnanya pembentukan akar merupakan salah satu hal yang tidak terlalu penting untuk dapat mencapai perawatan pulpotomi yang optimal. $^{5}$

Selanjutnya dipilih bahan kalsium hidroksida yang berbentuk campuran pasta base dan katalis. Bentuk campuran powder dan aquadest tidak dipilih karena bahan ini tidak cukup kuat menerima tekanan sewaktu pengisian bahan restorasi. Meskipun demikian campuran powder dan aquadest tetap masih dapat digunakan. ${ }^{10}$

Mengingat daerah pulpa pada saluran akar kini sudah terlindungi oleh bahan kalsium hidroksida, selanjutnya dipilih bahan semen ionomer kaca sebagai pendukung bahan pelindung. Semen ionomer kaca dipilih karena bahan ini mampu melepaskan flour dan memiliki koefesian termal ekspansi yang sama dengan jaringan gigi. Namun bahan ini juga memiliki beberapa kekurangan yaitu dari segi estetis. ${ }^{10}$

Setelah dilakukan pulpotomi dengan kalsium hidroksida, diketahui bahwa sudah terbentuk dentin sekunder pada minggu keempat. Menurut Ellis dan Davey pembentukkkan dentin sekunder setelah 6-8 minggu perawatan. Namun keberhasilan kasus ini sesuai dengan penelitian Lucia Blanco dan Stephen Cohen, bahwa pada dasarnya formasi awal dari dentin sekunder sudah terbentuk 7 hari setelah perawatan. ${ }^{5}$

Pada kontrol 6 bulan apeks telah tertutup sempurna sehingga gambaran radiolusensi menghilang. Hasil tersebut menunjukkan bahwa dengan mempertahankan pulpa tetap vital, maka perkembangan akar terus berlanjut. $^{3}$
Kemudian diberikan restorasi resin komposit sebagai temporary permanent restoration. Bahan ini digunakan sampai menunggu pasien usia dewasa sehingga baru dapat dilakukan permanent restoration. Resin komposit menghasilkan kualitas estetik yang baik, dapat dipoles dengan baik, dan mempunyai stabilitas warna untuk waktu yang cukup lama. ${ }^{10}$

Keberhasilan perawatan pulpotomi dengan kalsium hidroksida tergantung dari pemilihan kasus yang tepat dan prosedur perawatan yang benar. Pada kasus ini perawatan dilakukan setelah trauma terjadi selama seminggu. Pada minggu keempat setelah perawatan, hasil rontgen menunjukkan terbentuknya dentin sekunder. Dan 6 bulan setelah perawatan pemeriksaan radiograpik menunjukkan apeks tertutup sempurna. Kontrol secara periodik masih perlu dilakukan untuk melihat keadaan pulpa gigi tersebut.

\section{Daftar Pustaka}

1. Wei, S.H.Y., Pediatric Dentistry: Total Patient Care, Lea and Febiger, Philadelphia,1988, p.275-6.

2. Ellis, R.G and Davey,K.W. The Clasification and Treatment of Injuries To The Teeth of Children, ed.5 Year Book med.Pub,Chicago, 1970, p.14-7, 91-5.

3. Louis W. Ripa, Sidney B. Finn, The Care Of Injuries To the Anterior Teeth of Children, eds Finn, S.B, ed.4, W.B. Saunders Co, Philadelphia, London, Toronto,1973, p.231-5.

4. Andreasen, J.O, Traumatic Injuries of the Teeth, ed.1, Munkagoard,Copenhagen,Denmark,1972, p.15.

5. Lucian Blanco, Stephen Cohen, Treatment of Crown Fractures With Exposed Pulps, Journal of the California Dental Association, June 2002.

6. Richard R. Welbury, Paediatric Dentistry $2^{\text {nd }}$ ed. Oxford University Press,2001, p.226-9.

7. Craig,R.G, Restorative Dental Material, ed 7, Mosby Co, St Louis, Toronto, Priceton, 1985.

8. Cvek M, Granath L, Hard Tissue Barrier Formation in Pulpotomy with Calcium Hydroxide. J Dent Res 66: 1166- 74. 1987.

9. Jordan,RE, Restoration Fracturing and Hypoplastic Incisor by The Acid Etch Resin 
Perawatan Fraktur Kelas Tiga Ellis

Technique, a three year report, JADA vol 95, Oct 1997.

10. Slamat Tarigan, Sari Dental Material (Terjemahan dari Dental Material E.C. Combe), Balai Pustaka, 1992 p.144-6. 176-8. 